\title{
Selenocysteine-Specific Elongation Factor
}

National Cancer Institute

\section{Source}

National Cancer Institute. Selenocysteine-Specific Elongation Factor. NCI Thesaurus. Code C126628.

Selenocysteine-specific elong ation factor ( $596 \mathrm{aa}, \sim 65 \mathrm{kDa}$ ) is encoded by the human EEFSEC gene. This protein plays a role in the synthesis of selenocysteine-containing proteins. 